\title{
KEPEMIMPINAN KEPALA DESA DALAM MEWUJUDKAN DESA YANG MAJU DAN MANDIRI \\ ( Studi Multisitus pada Desa di Kecamatan Dringu Kabupaten Probolinggo)
}

\author{
Bukhari \\ Program Magister Manajemen Pasca Sarjana Universitas Gajayana Malang \\ hamengku_bumi@yahoo.com \\ Ernani Hadiyati \\ Program Magister Manajemen Pasca Sarjana Universitas Gajayana Malang \\ Sugeng Mulyono \\ Program Magister Manajemen Pasca Sarjana Universitas Gajayana Malang
}

\begin{abstract}
:
The village head's leadership is very influential on the progress of the village. Good village governance and quality village officials are able to bring villages to become independent in improving the welfare of village communities. Qualitative research with a multi-site method is needed to obtain in-depth information about the style and strategy, triggers and inhibiting factors, as well as the expectations of the leadership of the village head in the Dringu Subdistrict, Probolinggo Regency. A qualitative method with a multi-site approach was used in this study. This design was carried out guided by 3 stages of phenomenology, namely the intuitive stage, bracketing, analyzing and doing descriptive and interpretation. Unstructured interviews are used as the main method of data collection. There are 10 participants who have been saturated and based on participant criteria. The results of the study found 3 themes, namely (1) Leadership of innovative progressive and visioner village heads; (2) The duties and responsibilities of the village head are full time; (3) Hope to be an independent and participatory village.
\end{abstract}

Keywords: Leadership, Village Head, developed and independent villages. 


\section{PENDAHULUAN}

Desa mandiri saat ini menjadi isu penting yang perlu diperhatikan secara lebih serius serta didiskusikan lebih mendalam. Hal ini dikarenakan posisi desa sangat strategis untuk membangun sebuah Negara. Sebab, desa menjadi ujung tombak identifikasi masalah kebutuhan masyarakat di level akar rumput sampai perencanaan dan realisasi tujuan bernegara terdapat di tingkat desa (Sidik, 2015). Masalahnya adalah 60 persen penduduk Indonesia hidup di desa dan fakta menunjukkan bahwa mereka banyak mengalami permasalahan yang kompleks diantaranya; konflik, kesusakan lingkungan, pendidikan, kesehatan dan diperparah lagi dengan kondisi ketertinggalan perekonomian desa yang memicu meningkatnya jumlah angka kemiskinan Negara (Sandjojo, 2016).

Desa Membangun Indonesia dihadapkan pada kenyataan kemiskinan akibat rendahnya produktivitas masyarakat dan rendahnya kualitas lingkungan permukiman desa (Kolopaking, 2011). Data Badan Pusat statistik menunjukan bahwa wilayah desa adalah tempat di mana sebagian besar penduduk miskin tinggal. Untuk itu, ketersediaan data dan pengukuran dalam konteks ini sangat dibutuhkan, terutama dalam pengembangan intervensi kebijakan yang mampu menjawab persoalan dasar pembangunan dan pemberdayaan masyarakat Desa (Hamidi et al., 2015).

Lahirnya Undang-Undang nomor 6 tentang Desa telah memberikan ruang lebih bagi pemerintahan desa dibanding dengan masa sebelumnya. Pengambilan keputusan oleh komunitas desa dan berlangsung diluar pengaruh Negara atau pemerintah merupakan faktor penting yang menjadi pembeda dengan tata kelola pemeritahan desa sebelumnya (Agusta, Tetiani and Fujiartanto, 2014). Desa sebagai unit administrasi pemerintahan terkecil memegang peranan penting dan diharapkan menjadi titik awal berkembangnya titik awal pusat-pusat pertumbuhan perekonomian masyarakat (Pusat Data dan Informasi Kementerian Desa, 2015). Pembangunan perdesaan dilaksanakan dalam rangka intervensi untuk mengurangi tingkat kesejangan kemajuan antara wilayah perdesaan dan perkotaan sebagai akibat dari pembangunan ekonomi sebelumnya yang cenderung berorientasi pada wilayah perkotaan (Eko Sri Haryanto, 2015).

Di Indonesia khususnya di desa untuk melihat seberapa maju dan berkembangnya suatu desa dapat dilihat dari statusnya. Status desa ini dapat diketahui melalui kemajuan dan kemandirian desa yang ditetapkan berdasar indeks desa membangun, klasifikasi status desa tersebut meliputi desa mandiri, desa maju, desa berkembang, desa tertinggal dan desa sangat tertinggal (Peraturan Menteri Desa, Pembangunan Daerah Tertinggal, 2016). Dengan indikator inilah maka desa dapat menjadikannya sebagai instrumen atau alat ukur capaian pembangunan desa, sehingga pada indikator mana yang dinilai belum maupun telah tercapai dapat diketahui (Setyobakti, 2017). Berdasarkan data persentase jumlah desa di pulau Jawa ini, Provinsi Jawa Timur mendapat urutan kedua setelah Provinsi Jawa Tengah dengan kategori mandiri yang kecil dan masih tingginya kategori tertinggal.

Sesuai dengan Program Nawa Cita ke-3 yaitu "Membangun Indonesia dari Pinggiran dengan memperkuat daerah-daerah dan Desa dalam kerangka Negara Kesatuan", maka diperlukan tata kelola Pemerintahan Desa yang baik, dengan dukungan Aparatur Desa yang berkualitas dan kompeten dibidangnya, khususnya Kepala Desa (Syahrul K, Posumah and Dengo, 2017). Kepala Desa adalah pemimpin di Pemerintahan desa yang memiliki peran sebagai decision maker, strategic positioner, dan change agent untuk para Aparatur Desa yang lain. 
Kepala Desa harus memiliki manajemen pengetahuan yang baik dan pengalaman yang sesuai dengan jabatan yang diemban, seperti sistem pengelolaan keuangan, manajerial organisasi, perilaku organisasi, dan manajemen kinerja yang baik (Agustini, 2017).

Selain harus memiliki kompetensi yang sesuai, Kepala Desa juga harus kreatif dan inovatif dalam memimpin Desa yang menjadi tanggung jawabnya. Salah satu hal yang mendukung Kepala Desa dalam mengelola kompetensinya adalah pendidikan terakhir yang dimiliki oleh Kepala Desa yang bersangkutan. Namun sayangnya, berdasarkan data Kementerian Dalam Negeri per Desember 2017 tercatat bahwa, latar belakang pendidikan terakhir Kepala Desa secara umum masih didominasi pada tingkat SLTA yakni sebesar 21.921 (Agustini, 2017). Selain dari latar belakang pendidikan, ada beberapa sebab belum optimalnya pengelolaan dana desa oleh Kepala Desa, yaitu; 1) Seleksi Calon Kepala Desa yang belum mengedepankan kompetensi; 2) Tidak adanya Pendidikan dan Pelatihan serta sosialisasi secara merata mengenai aturan dan sanksi penggunaan Dana Desa; 3) Sebagian Dana Desa belum tersalurkan sesuai jadwal, karena masalah administrasi. Akibatnya menghambat program pemerintah untuk percepatan pembangunan (Onibala, Kiyai and Laloma, 2017).

Banyak penelitian mengatakan bahwa kepemimpinan Kepala Desa sangatlah berpengaruh kepada kemajuan desa, apabila kepemimpinan Kepala Desa berjalan baik maka akan terjadi penikatan kinerja organisasi, meningkatkan pula partisipasi masyarakat untuk kemajuan desanya (Eka Aprita Rati, Chotimah and Alfiandra, 2017; Lamangida, Akbar and Hasan, 2017; Nisa, 2018). Kepemimpinan Kepala Desa terbagi menjadi 3 tipe yaitu Kepemimpinan regresif, Kepemimpinan konservatif-involutif dan Kepemimpinan inovatif-progresif (Mustakim, 2015).

Berdasarkan fenomena yang sudah dipaparkan diatas betapa pentingnya kepemimpinan Kepala Desa yang inovatif-progresif mampu membawa desa membangun secara mandiri. Sudah Banyak penelitian secara kuantitatif dibeberapa daerah di Indonesia mencari gaya kepemimpinan Kepala Desa atau menghubungkan dengan variabel lainnya. Akan tetapi sangatlah jarang ditemukan penelitian secara mendasar (qualitatif) untuk menemukan secara subyektif dari pemimpin desa yang mampu membawa desanya secara mandiri, sehingga mampu memberikan inspirasi buat Kepala Desa lainnya tersebut.

Penelitian ini mempunyai tujuan: (1) Teridentifikasinya strategi dan tipe kepemimpinan; (2) Teridentifikasinya faktor pencetus dan penghambat kepemimpinan; (3) Teridentifikasinya harapan Kepala Desa di Desa Dringu, pabean dan sumber agung Kecamatan Dringu Kabupaten Probolinggo dalam mewujudkan desa maju dan mandiri.

\section{METODE PENELITIAN}

Penelitian ini menggunakan metode kualitatif dengan pendekatan studi multi situs, Sejalan dengan jenis penelitian studi multi situs, penelitian ini berusaha memahami makna peristiwa serta interaksi orang dalam situasi tertentu untuk dapat memahami makna peristiwa dan interaksi orang, digunakan orientasi teoritik atau perspektif teoritik dengan pendekatan fenomenologis (phenomenological approach).

Tempat penelitian yang dilakukan di 3 desa yaitu : Desa Dringu; Desa Pabean; dan Desa Sumber agung di kecamatan dringu Kabupaten Probolinggo. Terdapat 14 Informan yang tersaturasi dan sesuai dengan kriteria penelitian. Data diperoleh dengan teknik wawancara terbuka dan sebagai key informan Camat Dringu Kabupaten Probolinggo. Dalam melakukan 
pengumpulan data, peneliti merupakan instrumen utama dalam penelitian ini, selain itu peneliti juga menggunakan alat bantu berupa format pengumpulan data berisi data biografi, pertanyaanpertanyaan tertulis sebagai pedoman untuk wawancara, buku catatan dan alat tulis. serta perekam (Handphone) untuk merekam wawancara antara peneliti dengan informan.

Analisis data dilakukan setiap selesai mengumpulkan data dari satu partisipan. Hasil analisis dapat mengarahkan pada proses selanjutnya. Transkrip-transkrip dari hasil wawancara dan catatan lapangan (field notes) yang telah dibuat peneliti secara bersamaan di analisis. Teknik analisis spesifik dengan menggunakan pendekatan analisis selektif dan fokusing (the selective or highlighting approach) yang telah diuraikan oleh seorang fenomenologis, van Manen (1997), digunakan dalam analisis penelitian ini untuk mengungkapkan dan mengisolasikan berbagai aspek tematik dari fenomena-fenomena yang disoroti dalam penelitian ini.

Sebagai langkah terakhir, peneliti mempersiapkan tema-tema esensial yang merupakan suatu deskripsi paling terakhir dari fenomena yang terjadi (an exhaustive description of the phenomenom) yang merupakan deskripsi paling sempurna pengalaman-pengalaman para partisipan dengan kejadian pruritus. Alur analisis data dengan teknik analisis spesifik dengan menggunakan pendekatan analisis selektif dan fokusing (the selective or highlighting approach) dari Van Manen (1997) (Creswell, 2014).

\section{HASIL DAN PEMBAHASAN}

Penelitian ini mendapatkan 3 tema yaitu Kepemimpinan Kepala Desa yang inovatif, progresif dan visioner; Tugas dan tanggungjawab Kepala Desa penuh waktu; Harapan menjadi desa yang mandiri dan partisipatif

Tema 1 Kepemimpinan Kepala Desa yang inovatif, progresif dan visioner. banyak kategorik yang didapatkan dari persepsi informan tentang strategi dan tipe kepemimpinan Kepala Desa yang menginspirasi sehingga mampu kepala membawa desa menjadi maju.Tema Kepemimpinan Kepala Desa terdiri dari tiga sub tema yaitu: progresif, inovatif dan visioner. Sub tema progresif terdiri dari sembilan kategori yaitu promotor, aktif, pengalaman, pengetahuan, nilai, musyawarah, pelayanan, keterbukaan dan SDM (sumber daya manusia). Sedangkan sub tema inovatif terdiri dari tiga kategori diantaranya unggulan, potensi dan inovatif. Serta subtema visioner terdapat tiga kategorik yaitu pembangunan, strategi dan visi itu sendiri.

Kepemimpinan merupakan salah satu hal yang substansial dan krusial dalam kehidupan bermasyarakat, berNegara dan berbangsa, utamanya pada aspek pemerintahan, politik, ekonomi dan kemasyarakatan juga keagamaan. Hal ini menjadi fenomena yang paling sedikit dipahami dan paling banyak diamati. Fenomena kepemimpinan telah membuktikan bahwa kepemimpinan berpengaruh sangat besar terhadap kehidupan berNegara, berpolitik serta berpengaruh kuat terhadap jalannya organisasi dan kelangsungan hidupnya.

Untuk itu, pemimpin desa atau Kepala Desa menjadi poin penting dalam kemajuan desa. Dalam penelitian ini didapatkan bahwa Kepala Desa harus mampu menjadi pemimpin yang inovatif, sehingga dapat membawa kemajuan kepada desa yang dipimpinnya. Dari 3 situs ini, inovatif Kepala Desa berbeda-beda sebagaimana naluriah kepemimpinannya sehingga tercermin kepada strategi dan gaya dalam memimpin desa.

Pada dasarnya pembangunan yang dilaksanakan di desa yang dipimpin oleh Kepala Desa merupakan bagian integral dari pembangunan nasional. Hal ini berarti bahwa kepemimpinan 
Kepala Desa juga merupakan bagian dari kepemimpinan nasional. Kepala Desa sebagai penanggung jawab utama dibidang pemerintahan, pembangunan dan kemasyarakatan dituntut untuk mempunyai kemampuan dapat menggerakkan masyarakat desa untuk secara bersamasama berpartisipasi dalam pembangunan desa. Untuk dapat memenuhi kehendak dan kebutuhan masyarakat desa, sebagai aktualisasi kepemimpinannya, maka Kepala Desa harus mempunyai kemampuan untuk diterapkan dalam upaya menggerakkan dan mengarahkan serta mempengaruhi masyarakat yang dipimpinnya.

Kepala Desa yang merupakan suatu konsep terapan kepemimpinan yang diterapkan dalam pemerintahan desa. Seorang Kepala Desa harus bisa menjalankan dua peran, yaitu peran sebagai Kepala Desa yang merupakan kepemimpinan formal di desa, juga sebagai pimpinan social kemasyarakatan di desa yang dipimpinnya. Dimana kepala dea ini harus bisa mengintegrasikan sebagai seorang pemimpin formal pemerintahan desa yang juga kepanjangan tangan dari pemerintah, juga sebagai pempimpin sosial kemasyarakatan yang bisa menyambut dan menjadi saluran aspirasi masyarakat yang dipimpinnya.

Kepemimpinan inovatif-progresif, kepemimpinan tipe ini ditandai dengan adanya kesadaran baru mengelola kekuasaan untuk kepentingan masyarakat banyak. Model kepemimpinan ini tidak anti terhadap perubahan, membuka seluas-luasnya ruang partisipasi masyarakat, transparan serta akuntabel. Dengan pola kepemimpinan yang demikian Kepala Desa tersebut justru akan mendapatkan legitimasi yang lebih besar dari masyarakatnya.

Aspek paling fundamental dalam menjalankan kepemimpinan Desa adalah Legitimasi, hal ini terkait erat dengan keabsahan, kepercayaan dan hak berkuasa.legitimasi berkaitan dengan sikap masyarakat terhadap kewenangan. Kewenangan untuk memimpin, memerintah, serta menjadi wakil atau representasi dari masyarakatnya (Mustakim, 2015).

Kepala desa juga merupakan Servant leadership atau kepemimpinan pelayan. kepemimpinan pelayan sebagai pendekatan menyeluruh terhadap kepemimpinan yang melibatkan pengikut dan pemimpin dengan tujuan memberikan layanan. Pemimpin yang melayani bergantung pada keaslian, penekanan pada hubungan, keberanian moral, motivasi spiritual, dan pengaruh yang berubah untuk memungkinkan pemimpin dan pengikut untuk menjadi yang terbaik. Daripada berfokus pada tujuan organisasi, para pemimpin yang melayani memilih untuk menggunakan bakat mereka untuk membantu dalam pertumbuhan individu dan untuk mengelola organisasi melalui perubahan yang menekankan kesejahteraan. Dalam upaya mereka untuk membuat survei untuk mengukur kepemimpinan pelayan, van Dierendonck dan Nuijten (2011) mengoperasionalkan pemimpin pelayan sebagai seseorang yang etis dan berpusat pada orang dalam bagaimana mereka memimpin (pemberdayaan, akuntabilitas, keberanian, dan pengawasan), melayani (berdiri mundur), kerendahan hati, dan keaslian), dan kemampuan untuk memaafkan. Brutus dan Vanhove (2017) menyarankan enam kompetensi kepemimpinan pelayan yang mencakup aspek menjadi manajer yang baik serta layanan (mengutamakan pengikut), pemberdayaan (menanamkan rasa kompetensi dalam pengikut melalui komitmen terhadap pengembangan pribadi dan profesional), menciptakan visi dan arahan, penatalayanan (meninggalkan organisasi dalam kondisi yang lebih baik daripada sebelumnya), integritas, dan penghargaan antarpribadi (Horsman, 2018). 
Barbuto dan Wheeler (2006) menggunakan karya Greenleaf dan Spear dan menemukan lima sub-dimensi kepemimpinan pelayan: Panggilan altruistik (keinginan kuat untuk membuat perbedaan positif dalam anggota), penyembuhan emosional (mendorong pemulihan spiritual dari kesulitan, termasuk mendengarkan dan empati), kebijaksanaan (kemampuan untuk memproyeksikan situasi masa depan dan memahami lingkungan; kombinasi kesadaran dan pandangan ke depan), pemetaan persuasif (menggunakan penalaran logis dan kerangka kerja mental untuk mendorong anggota mencapai tujuan mereka), dan pengelolaan organisasi (mempersiapkan anggota untuk menambah untuk kesejahteraan masyarakat dengan menawarkan program pengembangan masyarakat dan layanan sukarela di masyarakat). Dengan definisidefinisi ini, ada banyak minat mengenai hubungan kesadaran-diri, nauthentisitas, moralitas, cinta, kepercayaan, dan spiritualitas dengan kepemimpinan yang melayani. Gagasan tentang topik ini akan ditawarkan secara lebih rinci (Horsman, 2018).

Tema 2 Tugas dan tanggungjawab Kepala Desa penuh waktu. Tema tugas dan tanggung jawab Kepala Desa terdapat tiga sub tema yaitu kegiatan non formal, pengabdian dan penghambat. Kepala Desa dalam mengembankan tugasnya sebagai pemimpin ibarat orang tua dengan anaknya, begitulah gambaran Kepala Desa dengan rakyatnya. Semua permasalan kehidupan rakyatnya menjadi permasalahan Kepala Desa yang harus terselesaikan.

Kepala Desa merupakan unsur pemerintahan yang paling dekat dengan masyarakat. Kepemimpinan Kepala Desa sangatlah dibutuhkan untuk dapat mensukseskan pelaksanaan pembangunan desa. Kepala Desa mempunyai tugas penyelenggaraan desa yaitu a). Urusan pemerintahan, antara lain pengaturan kehidupan masyarakat sesuai dengan kewenangan desa seperti, pembuatan peraturan deaa, pembentukan lembaga kemasyarakatan, pembentukan badan usaha milik daerah, dan kerja sama antar desa, b). Urusan pembangunan, antara lain pemberdayaan masyarakat dalam penyediaan sarana dan prasarana fasilitas umum desa seperti, jalan desa, jembatan desa, irigasi desa, psar desa. c). Urusan kemasyarakatan, yang meliputi pemberdayaan masyarakatmelalui pembinaan kehidupan sosial budaya masyarakat, seperti bidang kesehatan, pendidikan serta adat istiadat (Soemantr, 2011).

Selain itu Kepala Desa mempunyai kewajiban untuk memberikan laporan penyelenggaraan pemerintahan desa kepada Bupati/Walikota, memberikan laporan keterangn pertanggungjawaban kepada BPD, dan menginformasikan laporan penyelenggaraan pemerintahan desa kepada masyarakat.

Kepala Desa harus dapat memiliki fungsi sebagai pemimpin pada berbagai situasi dan perubahan. Karena kepala-yang-berkepemimpinan atau pemimpin-yang-adalah-kepala adalah pelopor, perintis, dan pemuka yang berada didepan, menerobos, menaklukan (mengantisipasi dan memberi solusi), mengintegrasikan dan memberi warna. Fungsi-fungsi itu ibara jarum dengan benang . dalam hubungan ini,benang adalah manajemen. Proses dan hasil-akhir setiap kegiatan ditentukan, tidak oleh salah satu melainkan oleh kedua-duanya. Jarum harus tajam dan benang harus kuat sehingga, dan sudah barang tentu, antara keduanya harus ada keserasian, keselarasandan keseimbangan (Ndraha, 2003). Lebih jauh Kartono (2001 : 33) menekankan, bahwa seorang pemimpin harus mampu melaksanakan fungsinya yang antara lain sebagai Memandu, menuntun, membangun, membimbing, memberitahu, membangun motivasi kerja, mengemudikan organisasi, menjalin jaringan-jaringan komunikasi yang baik, memberikan 
supervisi/pengawasan yang efisien dan membawa para pengikutnya kepada sasaran yang dituju sesuai dengan ketentuan waktu yang direncanakan (Kartono and Kartini, 2001).

Tema 3 harapan Kepala Desa menjadi desa yang mandiri dan partisipatif terdapat dua sub tema yaitu fisik dan non fisik. Harapan Kepala Desa banyak didapatkan dari sub non fisik terdapat tujuh kategori. Setiap pemimpin Kepala Desa yang inovatif, progresif, dan visioner akan menginkan sebuah kesuksesan dalam kepemimpinannya. Dalam hal ini menjadi desa yang mandiri dan partisipatif. Dari ketiga situs baik di Desa Dringu, pabean dan sumber agung sangat berharap kedepan bisa mewujudkan hal tersebut.

Undang-undang No. 6/2014 dilakukan rekonstruksi besar-besar terhadap pemahaman dan hakekat desa. UU ini bersemangatkan visi reformasi desa secara utuh. Visi reformasi Desa adalah menuju Desa yang mandiri, demokratis dan sejahtera. Karena berbasis visi itu, maka Desa tidak bisa dipahami hanya sebagai wilayah administratif atau tempat kediaman penduduk semata, melainkan sebagai entitas sosial, budaya, ekonomi, politik dan hukum. Paralel dengan visi tersebut, Desa ditransformasikan menjadi sebuah entitas yang bertenaga secara sosial, berdaulat secara politik, berdaya secara ekonomi dan bermartabat secara budaya. Otonomi Desa mengandung tiga makna: (a) Hak Desa untuk mempunyai, mengelola atau memperoleh sumberdaya ekonomi-politik; (b) Kewenangan untuk mengatur atau mengambil keputusan atas pengelolaan barang-barang publik dan kepentingan masyarakat setempat; dan (c) Tanggungjawab Desa untuk mengurus kepentingan publik (rakyat) Desa melalui pelayanan publik. Dengan demikian Desa mempunyai hak dan kewenangan jika berhadapan dengan pemerintah, sekaligus mempunyai tanggungjawab jika berhadapan dengan rakyat (Yarni, 2014).

Banyak pihak telah memahami, UU Desa memberi inspirasi dan semangat perubahan. Terkait Dana Desa misalnya, redistribusi asset Negara bersumber APBN itu membuktikan mampu menggerakan perubahan di Desa. Pembangunan Desa tumbuh menjadi kehebatan dan semangat baru dalam kehidupan Desa. Berdasar UU Desa tersebut, perubahan kehidupan Desa digerakan dalam kerangka kerja: pengertian dan jenis Desa (yakni Desa dan Desa Adat atau yang disebut dengan nama lain), tujuan pengaturan, azas-azas, kedudukan, kewenangan, keuangan dan asset, tata pemerintahan, kelembagaan masyarakat dan adat, pemberdayaan masyarakat Desa, pembangunan Desa dan Kawasan Perdesaan, dan berikut dukungan pendamping Desa dan sistem informasi Desa. Dalam kontekstual relevansi itulah IDM dikembangkan.

Azas-azas yang menjadi dasar pengaturan Desa dalam UU Desa dikuatkan dengan penegasan tentang Kewenangan Desa. Kewenangan Desa itu sendiri dijelaskan meliputi kewenangan yang meliputi penyelenggaraan pemerintahan Desa, pelaksanaan pembangunan Desa, pembinaan kemasyarakatan Desa, dan pemberdayaan masyarakat Desa berdasarkan prakarsa masyarakat, hak asal usul, dan adat istiadat Desa. Dalam fokus kewenangan berdasar hak asal usul dan kewenangan lokal berskala Desa, tiga hal yang disebut terakhir, yakni: prakarsa masyarakat, hak asal usul dan adat istiadat Desa itu akan memperkuat pondasi otonomi Desa. Dan dalam kerangka pemahaman itulah, pendekatan Indeks Desa Membangun dikembangkan. IDM memandang penting prakarsa dan kuatnya masyarakat Desa dalam proses kemajuan dan keberdayaan kehidupan Desa yang di dalamnya memiliki ketahanan sosial, ekonomi dan ekologi.

Indeks Desa Membangun mengklasifikasi Desa dalam lima (5) status, yakni: (i) Desa Sangat Tertinggal; (ii) Desa Tertinggal; (iii) Desa Berkembang; (iv) Desa Maju; dan (v) Desa 
Mandiri. Klasifikasi Desa tersebut untuk menunjukkan keragaman karakter setiap Desa dalam rentang skor 0,27 - 0,92 Indeks Desa Membangun. Klasifikasi dalam 5 status Desa tersebut juga untuk menajamkan penetapan status perkembangan Desa dan sekaligus rekomendasi intervensi kebijakan yang diperlukan. Status Desa Tertinggal, misalnya, dijelaskan dalam dua status Desa Tertinggal dan Desa Sangat Tertinggal di mana situasi dan kondisi setiap Desa yang ada di dalamnya membutuhkan pendekatan dan intervensi kebijakan yang berbeda. Menangani Desa Sangat Tertinggal akan berbeda tingkat afirmasi kebijakannya di banding dengan Desa Tertinggal.

Desa Berkembang terkait dengan situasi dan kondisi dalam status Desa Tertinggal dan Desa Sangat Tertinggal dapat dijelaskan dengan faktor kerentanan. Apabila ada tekanan faktor kerentanan, seperti terjadinya goncangan ekonomi, bencana alam, ataupun konflik sosial maka akan membuat status Desa Berkembang jatuh turun menjadi Desa Tertinggal. Dan biasanya, jika faktor bencana alam tanpa penanganan yang cepat dan tepat, atau terjadinya konflik sosial terus terjadi berkepanjangan maka sangat potensial berdampak menjadikan Desa Tertinggal turun menjadi Desa Sangat Tertinggal. Sementara itu, kemampuan Desa Berkembang mengelola daya, terutama terkait dengan potensi, informasi / nilai, inovasi / prakarsa, dan kewirausahaan akan mendukung gerak kemajuan Desa Berkembang menjadi Desa Maju.

Klasifikasi status Desa berdasar Indeks Desa Membangun ini juga diarahkan untuk memperkuat upaya memfasilitasi dukungan pemajuan Desa menuju Desa Mandiri. Desa Berkembang, dan terutama Desa Maju, kemampuan mengelola Daya dalam ketahanan sosial, ekonomi, dan ekologi secara berkelanjutan akan membawanya menjadi Desa Mandiri.

Lalu, bagaimana mewujudkan kemandirian desa?.Berkait dengan pertanyaan ini, sesungguhnya telah banyak desa-desa yang sudah merintis kemandirian desa tanpa menunggu kehadiran pemerintah supradesa. Tak terkecuali desa para pembaca yang budiman.Silakan dicermati desa kita, pasti ada pertikan-pertikan inovasi lokal yang itu menunjukkan keberdayaan dan kemandirian desa. Belajar pada berbagai praktik inovatif dan emansipatif yang tumbuh dari dalam desa-desa diberbagai belahan negeri Indonesia, dapat ditarik beberapa strategi yang semoga layak diterapkan.

Langkah sederhananya pertama, mendorong lahirnya warga dan organisasi warga desa yang kritis, peduli dan berinteraksi dinamis dengan proses-proses pengambilan kebijakan pembangunan desa.kedua, menjalankan sistem perencanaan dan penganggaran desa yang partisipatif, akuntabel, dan transparan sesuai dengan batas kewenangan yang dimiliki. Ketiga,memberdayan lembaga dan kelembagaan ekonomi desa yang inklusif. Tambahan pula, kesuksesan pencapaian desa mandiri di lain pihak juga ditopang oleh implementasi system perencanaan, penganggaran dan pelaksanan anggaran desa yang partisipatif, tertib, efektif, efisien dan disertai monitoring yang baik (Kurniawan, 2015).

\section{KESIMPULAN}

Kepemimpinan Kepala Desa sangatlah penting dalam perkembangan desa. Untuk itu, diperlukan Kepemimpinan Kepala Desa yang inovatif, progresif dan visioner. Selain itu, menjadi Kepala Desa tidaklah mudah, tidak ada batasan waktu dalam melayani masyarakatnya bahkan mengorbankan kepentingan sendiri demi kepentingan rakyatnya. Harapan menjadi desa mandiri dan partisipatif merupakan cita-cta setiap Kepala Desa yang bertanggung jawab. 


\section{DAFTAR PUSTAKA}

Agusta, Tetiani and Fujiartanto (2014) Indeks Kemandirian Desa Metode, Hasil, dan Alokasi Program Pembangunan. Jakarta: Yayasan Obor Indonesia.

Agustini, F. N. (2017) 'Pentingnya Kompetensi Kepala Desa Sebagai Syarat Keberhasilan Pengelolaan Dana Desa', Buletin APBN Pusat Kajian Anggaran Badan Keahlian DPR RI, p. 9.

Creswell, J. W. (2014) Penelitian kualitatif dan desain riset memilih di antara lima pendekatan (bahasa ind). Yogyakarta: Pustaka Pelajar.

Eka Aprita Rati, Chotimah, U. and Alfiandra (2017) 'Pengaruh Kepemimpinan Kepala Desa Terhadap Partisipasi Masyarakat Dalam Pembangunan Desa Di Desa Sako Makmur Kecamatan Sembawa Kabupaten Banyuasin', Jurnal Bhinneka Tunggal Ika, 4(1), pp. 7180.

Eko Sri Haryanto (2015) Pengembangan Desa. 1st edn. Jakarta: Kementerian Desa, Pembangunan Daerah Tertinggal Dan Transmigrasi Republik Indonesia.

Hamidi, H. et al. (2015) Indeks Desa Membangun 2015. Jakarta.

Horsman, J. H. (2018) Servant-Leaders in Training. Cham: Springer International Publishing. doi: 10.1007/978-3-319-92961-3.

Kartono and Kartini (2001) Pemimpin Dan Kepemimpinan. Jakarta: Raja Grafindo Persada.

Kolopaking, L. . (2011) 'Peningkatan Kapasitas dan Penguatan Struktur Kelembagaan Otonomi Desa', in Menuju Desa 2030. Bogor: Crestpent Press KAntor Pusat Pengkajian Perencanaan dan Pengembangan Wilayah (P4W) IPB, pp. 133-146.

Kurniawan, B. (2015) DESA MANDIRI, DESA MEMBANGUN. 1st edn. Jakarta: Kementerian Desa, Pembangunan Daerah Tertinggal dan Transmigrasi.

Lamangida, T., Akbar, M. F. and Hasan, H. (2017) 'Kepemimpinan Kepala Desa Dalam Membangun Desa Bandung Rejo Kecamatan Boliyohuto', Jurnal Ilmu Administrasi, 6(1).

Mustakim, M. Z. (2015) Kepemimpinan Desa. 1st edn. Jakarta: Kementerian Desa, Pembangunan Daerah Tertinggal, Dan Transmigrasi Republik Indonesia.

Ndraha, T. (2003) Kybernology(Ilmu Pemerintahan Baru). Jakarta: PT Rineka Cipta.

Nisa, S. K. (2018) 'Pengaruh Tingkat Kepemimpinan Kepala Desa Dan Tingkat Kompetensi Aparatur Desa Terhadap Tingkat Kinerja Organisasi Badan Usaha Milik Desa (Studi Pada Bumdes Maju Makmur Desa Minggirsari Kecamatan Kanigoro Kabupaten Blitar)', Kebijakan dan Manajemen Publik, 6(3).

Onibala, M., Kiyai, B. and Laloma, A. (2017) 'Kinerja Kepala Desa Dalam Pelaksanaan Pembangunan Desa Di Desa Tolok Satu Kecamatan Tompaso', Jurnal Administrasi Publik, 3(46).

Peraturan Menteri Desa, Pembangunan Daerah Tertinggal, dan T. R. I. (2016) Indeks Desa Membangun. Indonesia.

Pusat Data dan Informasi Kementerian Desa, P. dan T. (2015) Data dan Informasi Penyiapan Pembangunan Daerah Tertinggal. Jakarta. Available at: Pusat Data dan Informasi Kementerian Desa, PDT dan Transmigrasi.

Sandjojo, E. P. (2016) 'Pengantar Menteri Desa, Kementerian Desa', in Nisa, N. (ed.) Buku Panduan Pelaksanaan Undang-Undang Desa Berbasis Hak. 1st edn. Jakarta: Lakpesdam PBNU, p. iv.

Setyobakti, H. M. (2017) 'Identifikasi masalah dan potensi desa berbasis indek desa membangun (idm) di desa gondowangi kecamatan wagir kabupaten malang', Jurnal Penelitian Ilmu Ekonomi WIGA, 7(1), pp. 1-14. 
Sidik, F. (2015) 'Menggali Potensi Lokal Mewujudkan Kemandirian Desa', JKAP (Jurnal Kebijakan dan Administrasi Publik), 19(2), p. 115. doi: 10.22146/jkap.7962.

Soemantr, B. T. (2011) Pedoman Penyelenggaraan Pemerintahan Desa. Bandung: Fokus Media. Syahrul K, Posumah, J. H. and Dengo, S. (2017) 'Kompetensi Kepala Desa Dalam Penyelenggaraan Pemerintahan Di Desa Tounelet Kecamatan Kakas Kabupaten Minahasa', Jurnal Administrasi Publik, 3(46).

Yarni, M. (2014) 'Menuju Desa Yang Maju, Kuat, Mandiri, Dan Demokratis Melalui Undang Undang No. 6 Tahun 2014 Tentang Desa', Inovatif, 7(2). 